\title{
KECERDASAN EMOSIONAL DAN PENYESUAIAN SOSIAL
}

\author{
Puspa Rahayu Utami Rahman \\ puspa.rahman@ubpkarawang.ac.id
}

\section{Fakultas Psikologi Universitas Buana Perjuangan Karawang}

\begin{abstract}
Abstrak. Penelitian ini bertujuan untuk mengetahui hubungan yang signifikan antara kecerdasan emosional dengan penyesuaian sosial mahasiswa Fakultas Ilmu Pendidikan Universitas Pendidikan Indonesia. Pendekatan yang digunakan adalah pendekatan kuantitatif dengan metode deskripsi korelasional. Sampel penelitian adalah 100 mahasiswa FIP UPI yang diambil dengan teknik Incidental Sampling. Alat ukur yang digunakan berupa kuesioner kecerdasan emosional yang disusun berdasarkan alat ukur Emotional Competence Inventory dari Boyatzis \& Goleman (2005) dan kuesioner penyesuaian sosial berdasarkan teori Schneider (1964). Sedangkan teknik analisis yang digunakan adalah korelasi Pearson Product Moment. Hasil penelitian menunjukkan terdapat hubungan yang signifikan dan positif antara kecerdasan emosional dengan penyesuaian sosial mahasiswa FIP UPI dengan diperoleh koefisien korelasi sebesar $+0,614$ dengan probabilitas 0,000 yang bermakna $\mathrm{H}_{0}$ ditolak dan $\mathrm{H}_{\mathrm{a}}$ diterima.
\end{abstract}

Kata kunci: kecerdasan emosional, penyesuaian social, mahasiswa

\begin{abstract}
The purpose of this research was to find out correlation between emotional intelligence with social adjustment. Research sample was 100 students FIP UPI that taken by incidental sampling technique. The approach used is a quantitative approach with correlational method. the instrument used is emotional intelligence questionnaire based on the Emotional Competence Inventory from Boyatzis \& Goleman (2005) and social adjustment questionnaire based on the theory of Schneider (1964). The analytical techniques used is the Pearson Product Moment correlation. Result of the research indicates that there were significant and positive correlation between emotional intelligence with social adjustment of students FIP UPI with the correlation coeficient of variables $+0,614$.
\end{abstract}

Keywords: emotional intelligence, social adjustment, students 


\section{Pengantar}

Manusia dalam kehidupannya
akan melalui beberapa tahap perkembangan, salah satunya yaitu masa remaja. Masa ini merupakan salah satu periode yang penting dan mempunyai resiko dalam rentang kehidupan manusia. Karena sesuatu yang terjadi di masa ini berakibat langsung dan berjangka panjang terhadap sikap dan perilaku remaja. Sebagai peralihan dari masa anak menuju masa dewasa, masa remaja merupakan masa yang penuh dengan kesulitan dan gejolak dalam diri, salah satunya adalah gejolak emosi. Menurut Goleman (2007: 411) emosi merujuk pada suatu perasaan dan pikiran-pikiran khasnya, suatu keadaan biologis dan psikologis, dan serangkaian kecenderungan untuk bertindak. Contoh pengungkapan dari perasaan emosi seperti amarah, kesedihan, rasa takut, kenikmatan, cinta, terkejut, jengkel dan malu. Ketidakmampuan remaja dalam menjalin relasi antar-pribadi diakibatkan kecerdasan emosional yang rendah. Seperti yang diungkapkan oleh Salovey dalam Goleman (2007: 57-59), kecerdasan emosional adalah mengenali emosi diri, mengelola emosi, memotivasi diri sendiri, mengenali emosi orang lain, dan membina hubungan dengan orang lain.

Namun dikarenakan masa remaja merupakan masa badai dan tekanan, yaitu masa dimana ketegangan emosi meninggi sehingga remaja mengalami ketidakstabilan emosi yang menyebabkan emosi pada masa remaja menjadi mudah terangsang dan cenderung meledak-ledak (Hurlock, 1980). Ketidakstabilan emosi tersebut dapat menimbulkan konflik dan gangguan emosional yang berkaitan dengan diri sendiri maupun orang lain serta kegagalan-kegagalan dalam menjalin kehidupan.

Contoh kasus yang

dikemukakan oleh Thobias (2008), yaitu bentrok fisik antara mahasiswa Fakultas Hukum Universitas Negeri Nusa Cendana dan mahasiswa Politeknik Pertanian Negeri Kupang di Kupang, Nusa Tenggara Timur, Senin (17/11/2008), menyebabkan satu orang tewas dan sembilan luka-luka. Peristiwa itu berawal dari saling ejek. Tidak hanya merusak aset-aset kampus, tetapi juga menimbulkan korban luka-luka, bahkan meminta tumbal nyawa seorang mahasiswi belia, Seselia Radja (19). Sebagaimana diberitakan, Sesilia pingsan di area bentrokan dan sempat dilarikan ke rumah sakit, namun nyawanya tidak tertolong. Diperkirakan ia meninggal dalam perjalanan. Hanya terselang beberapa jam dengan bentrokan mahasiswa di Kupang, tawuran mahasiswa pun pecah di Makassar-Sulawesi Selatan, Senin (17/11/2008), yang melibatkan mahasiswa Universitas Muhammadiyah Makassar (UMM). Dua hari sesudahnya, Rabu (19/11/2008), tawuran mahasiswa kembali pecah di Makassar, kali ini di kampus Universitas 45. Belum lama setahun berselang, Jumat (16/10/2009), terjadi tawuran antar mahasiswa di ibu kota negara, yakni antara mahasiswa Universitas Persada YAI versus mahasiswa Universitas Kristen Indonesia (UKI). Sejumlah mahasiswa Fakultas Ilmu Sosial dan Politik dan Fakultas Hukum UPI YAI bekerja sama menyerang sekelompok mahasiswa Fakultas Teknik UKI. Dan terjadi aksi lempar batu antar mahasiswa kedua kampus. Sedikitnya empat mahasiswa 
dari dua kampus terluka dan dilarikan ke rumah sakit (Noorastuti, 2009). Pada awal tahun, tepatnya Kamis (18/02/10), tawuran mahasiswa pecah di kampus Universitas Hasanuddin, Makassar, Sulawesi Selatan. Dua kelompok yang bertikai berasal dari Fakultas Teknik dan Fakultas Peternakan. Kedua kelompok beradu lempar batu. Akibatnya, tiga mahasiswa jadi korban dan menderita luka-luka. Aksi itu dipicu salah paham antara kedua kelompok. Sebelum kejadian, mahasiswi dari Fakultas Teknik menggelar pasar murah jajanan dan memasuki area Fakultas Peternakan. Mereka pun jadi sasaran pelecehan mahasiswa peternakan (Media Indonesia, 2010)

Selain bentrokan mahasiswa, terjadi pula kasus bunuh diri mahasiswa, yaitu seorang mahasiswa Fakultas Ekonomi Universitas Persada Indonesia YAI, Hendrawan Winata (25), terjun dari Gedung Fakultas Ekonomi lantai 6 Kampus Universitas Kristen (Unika) Atmajaya, Jalan Jenderal Sudirman, Jakarta Selatan, Senin (15/12/2008) siang, diduga bunuh diri karena depresi karena kuliahnya tak kunjung selesai. Hendrawan Winata ditemukan tewas setelah terjun dari Gedung Fakultas Ekonomi lantai 6 Unika Atmajaya dengan kondisi kepala dan tubuhnya remuk (Kapanlagi, 2008). Nova Mirawati, 20 tahun, mahasiswi Fakultas Psikologi Universitas Indonesia yang bunuh diri dengan menjatuhkan diri dari lantai tujuh di Gedung Pusat Grosir Cililitan (PGC), Jakarta Timur dan meninggal dunia. Korban mengalami luka patah di sekujur tubuh. Saat itu Nova langsung dilarikan ke Rumah Sakit Universitas Kristen Indonesia. Menurut dokter, korban mengalami luka serius di sekitar kepala, dada, perut hingga kaki.
Menurut hasil scanning, Nova juga mengalami pendarahan di perut. Nova melakukan itu diduga karena stres berat hingga menempuh jalan pintas (Metrotvnews, 2008).

Fenomena di atas mencerminkan adanya ketidakstabilan emosi yang dialami remaja dan permasalahan dalam menyesuaikan diri di lingkungannya. Hal ini menunjukkan bahwa emosi memainkan peranan penting pada penyesuaian diri remaja. Pada usia ini remaja harus bisa memiliki kematangan emosi dalam berperilaku dan berpikir agar tidak merugikan dirinya sendiri, juga tidak merugikan orang lain.

\begin{tabular}{ll}
\multicolumn{2}{c}{ Hasil penelitian Kamelia (2003) } \\
mengenai "Hubungan Antara
\end{tabular}

Kecerdasan Emosi dengan Penyesuaian Sosial di Sekolah pada Siswa Kelas II SMU PGII II Bandung" mengatakan bahwa kecerdasan emosional dan penyesuaian sosial di sekolah mempunyai korelasi yang cukup berarti. Selain itu hasil penelitian Effendi (2003) mengenai "Hubungan Antara Emotional Intelligence dengan Penyesuaian Sosial di Sekolah pada Siswa Kelas III SMUN 7 Bandung" dapat disimpulkan bahwa terdapat hubungan positif yang signifikan antara emotional intelligence dengan penyesuaian sosial pada siswa kelas III SMUN 7 Bandung, sehingga semakin rendah emotional intelligence yang dimiliki siswa kelas II SMUN 7 Bandung maka semakin rendah penyesuaian sosial yang dilakukan oleh siswa baik di rumah, sekolah dan masyarakat. Remaja yang memiliki keterampilan emosional yang berkembang dengan baik lebih memiliki peluang untuk dapat hidup dengan bahagia dan berhasil dalam 
kehidupannya, termasuk dalam penyesuaian sosialnya.

Schneider

mendefinisikan penyesuaian sosial sebagai kemampuan seseorang dalam bereaksi secara efektif dan sehat terhadap apa yang dihadapinya sehingga kebutuhannya dapat terpenuhi dengan cara yang bisa diterima dan memuaskan. Schneider (1964) membagi penyesuaian sosial menjadi tiga bagian lingkungan, salah satunya adalah penyesuaian sosial di lingkungan kampus yang meliputi aspek menghargai dan mau menerima otoritas kampus, tertarik dan berpartisipasi dalam kegiatan kampus, mempunyai hubungan sosial yang sehat, bersahabat dengan teman, dosen dan unsur-unsur kampus lainnya, menerima batasan dan tanggung jawab sebagai mahasiswa, serta membantu kampus mencapai tujuan intrinsik dan ekstrinsik.

Hurlock (1980) mengatakan bahwa salah satu tugas perkembangan masa remaja yang tersulit adalah yang berhubungan dengan penyesuaian sosial. Sedangkan pada kenyataannya, tidak semua remaja mempunyai kemampuan penyesuaian sosial yang baik. Masih terdapat mahasiswa yang memiliki ketidakstabilan emosi, berperilaku tidak sesuai harapan, kurang berempati dan sukar membina hubungan yang baik dengan orang lain.

Berdasarkan hasil penggalian data awal terhadap mahasiswa FIP UPI didapatkan bahwa masih ada mahasiswa yang sering terlambat masuk kelas, berpakaian tidak sesuai aturan seperti memakai celana berbahan jeans yang tidak diperbolehkan bagi mahasiswa jurusan PPB, rambut yang gondrong atau melebihi kerah bagi laki-laki, tidak hadir dalam perkuliahan tanpa keterangan bahkan menitipkan absen pada temannya, menyontek ketika ujian maupun mengerjakan tugas kuliah, tidak menghormati dosen tertentu ketika sedang menjelaskan.

Selain itu dilakukan wawancara terhadap beberapa dosen dijelaskan bahwa mahasiswa FIP UPI memiliki kurangnya motivasi diri dan membina hubungan yang lebih akrab dengan dosen dan senior. Misalnya kurang ada rasa hormat, seperti memanggil kakak angkatan dengan namanya langsung bahkan terkadang tidak menyapa ketika berpapasan. Ada juga beberapa mahasiswa yang merespon tidak baik ketika dosen mengingatkan bahwa mahasiswa tersebut tidak mematuhi aturan praktikum.

Dengan memperhatikan fenomena kehidupan remaja serta pentingnya kecerdasan emosional dalam memberikan sumbangan di kehidupan sosial, serta bertolak dari latar belakang masalah tersebut di atas, maka penelitian ini berfokus pada "Hubungan Antara Kecerdasan Emosional dengan Penyesuaian Sosial".

\section{Metode Penelitian}

Penelitian ini menggunakan pendekatan kuantitatif. Jumlah sampel sebanyak 100 mahasiswa dan berusia 18 hingga 21 tahun. Teknik pengambilan sampel yang digunakan adalah incidental sampling. Tempat pelaksanaan penelitian adalah di Fakultas Ilmu Pendidikan Universitas Pendidikan Bandung.

Dalam penelitian ini alat ukur yang digunakan berupa kuesioner. Yaitu kuesioner kecerdasan emosional yang didasarkan pada alat ukur Emotional Competence Inventory dari Boyatzis dan Goleman (2005). Dan kuesioner penyesuaian sosial yang dikembangkan sendiri oleh peneliti berdasarkan teori Schneider (1964). Uji validitas 
instrumen didasarkan pada validitas isi dan mencari korelasi antara tiap-tiap item skor total item (daya diskriminasi item). Pengujian reliabilitas instrumen dengan menggunakan rumus Alpha Cronbach. Sementara itu, untuk mengetahui ada atau tidaknya hubungan antara variabel satu (kecerdasan emosional) dan variabel dua (penyesuaian sosial) dilakukan uji korelasi Pearson Product Moment dengan bantuan software SPSS Versi 15.0 for windows.

\section{Hasil Penelitian Dan Pembahasan Hasil Penelitian}

Secara umum kecerdasan emosional mahasiswa FIP UPI dalam kategori sedang. Dari 100 subjek yang diteliti, sebanyak 12 subjek memiliki kecerdasan emosional yang tinggi, 74 subjek memiliki kecerdasan emosional sedang, dan sebanyak 14 subjek yang memiliki kecerdasan emosional rendah. Apabila digambarkan dalam bentuk grafik akan diperoleh visualisasi sebagai berikut:

\section{Grafik 1}

Kategorisasi Kecerdasan Emosional Mahasiswa FIP UPI

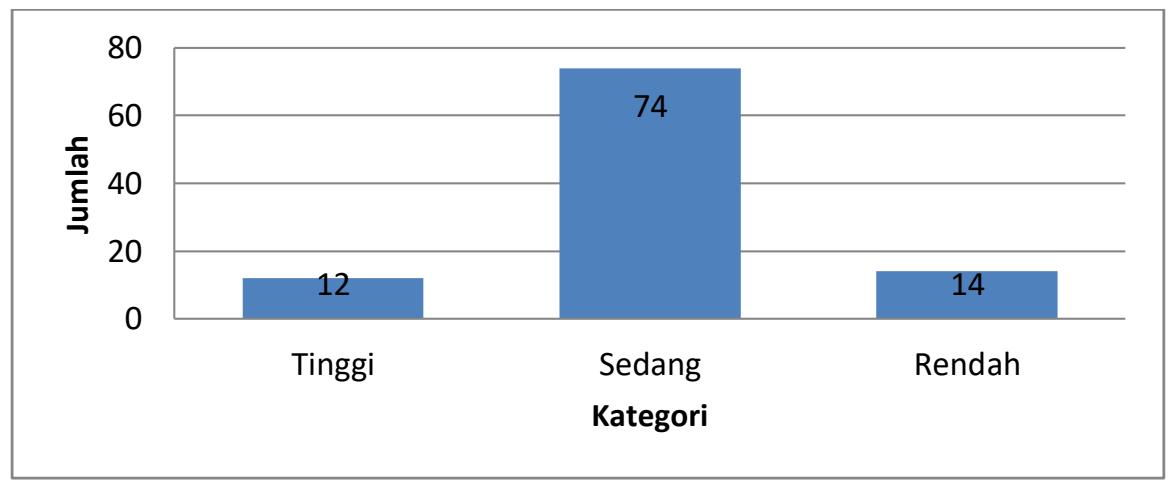

Secara umum penyesuaian sosial mahasiswa FIP UPI dalam kategori sedang. Dari 100 subjek yang diteliti, sebanyak 18 subjek memiliki penyesuaian sosial yang baik, 65 subjek memiliki penyesuaian sosial sedang, dan sebanyak 17 subjek memiliki penyesuaian sosial buruk. Apabila digambarkan dalam bentuk grafik akan diperoleh visualisasi sebagai berikut:

\section{Grafik 2}

Kategorisasi Penyesuaian Sosial Mahasiswa FIP UPI 


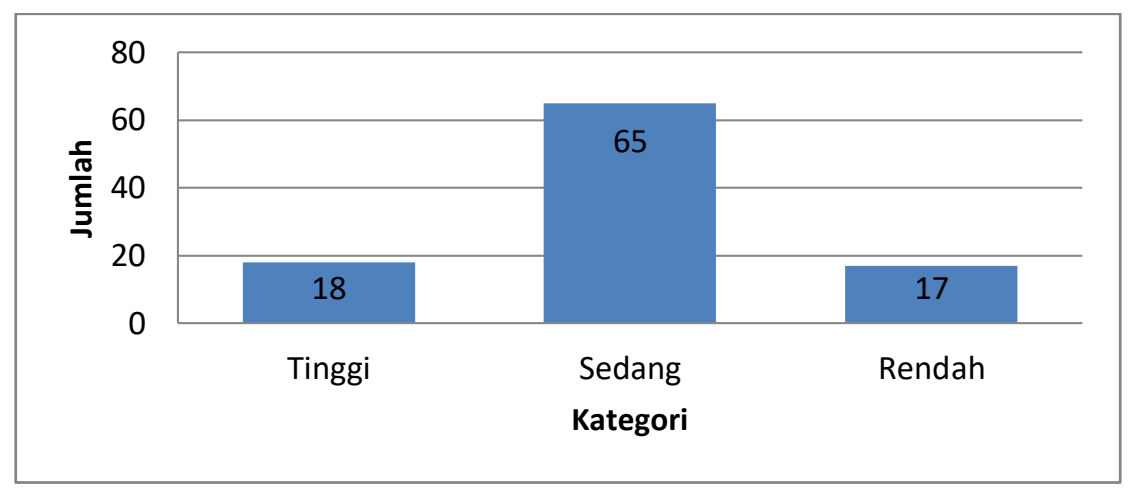

Hasil penelitian menunjukkan bahwa terdapat hubungan yang signifikan antara kecerdasan emosional dengan penyesuaian sosial mahasiswa FIP UPI, dengan koefisien korelasi sebesar $+0,614$, hal ini menunjukkan bahwa hubungan tersebut berada pada kategori kuat. Selain hubungan yang signifikan dan kuat, hubungan tersebut bernilai positif, artinya semakin tinggi kecerdasan emosional mahasiswa maka semakin baik penyesuaian sosial mahasiswa. Sebaliknya semakin rendah kecerdasan emosional maka semakin buruk pula penyesuaian sosialnya.

\section{Pembahasan}

Hasil penelitian menunjukkan bahwa terdapat hubungan yang signifikan antara kecerdasan emosional dengan penyesuaian sosial mahasiswa FIP UPI, dengan koefisien korelasi sebesar $+0,614$. Nilai koefisien korelasi tersebut menunjukkan bahwa hubungan antara kecerdasan emosional dengan penyesuaian sosial mahasiswa FIP UPI berada pada kategori kuat. Selain hubungan yang signifikan, koefisien korelasi tersebut bernilai positif, artinya semakin tinggi kecerdasan emosional mahasiswa maka semakin baik penyesuaian sosial mahasiswa. Sebaliknya semakin rendah kecerdasan emosional maka semakin buruk pula penyesuaian sosialnya. Temuan ini sejalan dengan hasil penelitian yang telah dilakukan oleh Purnama (2008) bahwa terdapat hubungan yang signifikan dan positif antara kecerdasan emosional dengan penyesuaian sosial di sekolah pada siswa kelas XI SMAN 1 Cicalengka. Hal ini menunjukkan bahwa faktor keberhasilan seseorang ternyata bukan semata-mata ditentukan oleh faktor pendidikan formal dan kecerdasan intelektual tetapi kontribusi terbesar yang mendukung keberhasilan seseorang adalah kecerdasan emosional. Hal ini sejalan dengan apa yang diungkapkan oleh Goleman (2007) bahwa keberhasilan seseorang 20\% ditentukan oleh IQ dan $80 \%$ diisi oleh kekuatan-kekuatan lain dan kecerdasan emosional merupakan faktor penting yang memberikan sumbangan besar bagi keberhasilan individu dalam kehidupan, baik di bidang akedemis, karir, maupun dalam kehidupan sosial. Dilanjutkan oleh Schneider (1964: 274) bahwa emosi yang tidak berlebihan atau tidak adanya gangguan dalam emosi merupakan bentuk penyesuaian diri atau sosial yang normal, artinya individu yang memiliki ketenangan emosional dan kontrol mampu menilai situasi dengan baik dan mengatur mengatasi kesulitan apapun yang ada.

Koefisien determinasi yang ditunjukkan oleh $R$ square adalah 0,376. Angka tersebut mengandung pengertian bahwa pada penelitian ini kecerdasan 
emosional memberikan sumbangan efektif sebesar $37,6 \%$ terhadap penyesuaian sosial mahasiswa FIP UPI. Hal ini berarti $62,4 \%$ sisanya, kemungkinan ditentukan oleh faktor lain, seperti yang diungkapkan oleh Schneider (1964: 122) yaitu faktor keadaan fisik, perkembangan dan kematangan, keadaan psikologis, keadaan lingkungan yaitu sekolah dan keluarga, serta tingkat religiusitas dan kebudayaan.

Menurut Schneider (1964), keadaan sistem-sistem tubuh yang baik merupakan syarat bagi terciptanya penyesuaian diri yang baik. Sehubungan dengan hal ini, dapat dikatakan adanya cacat fisik, kelemahan fisik, penyakit kronis dan kekurangankekurangan lainnya akan melatarbelakangi adanya hambatan pada individu dalam melaksanakan penyesuaian diri. Kondisi fisik lain yang dapat mempengaruhi adalah konstitusi fisik, orang yang memiliki penampilan fisik yang menarik cenderung disukai sehingga lebih mudah diterima dalam melakukan penyesuaian di lingkungannya dibandingkan dengan orang yang penampilannya kurang menarik.

Faktor berikutnya adalah faktor perkembangan dan kematangan. Perkembangan dan kematangan akan mempengaruhi level penyesuaian individu, beberapa diantaranya adalah kematangan emosional, intelektual, sosial, dan moral (Schneider, 1964). Pada penelitian ini kematangan yang diungkap adalah kematangan emosional. Individu yang lebih matang secara emosional akan lebih mudah melakukan penyesuaian dibandingkan dengan orang yang kurang matang karena ia lebih mampu mengendalikan diri dan bereaksi sesuai situasi yang dihadapi.

Faktor psikologis pun merupakan salah satu faktor mempengaruhi penyesuaian diri individu yang meliputi pengalaman, proses belajar, pembiasaan, frustrasi, dan konflik (Schneider, 1964). Mahasiswa yang memiliki mental sehat akan lebih mampu menyesuaikan diri dan mampu memberikan respon yang selaras dengan dorongan internal maupun tuntutan lingkungannya. Sementara mahasiswa yang frustrasi dan cemas akan mengalami kesulitan dalam melakukan penyesuaian terhadap perubahan dan tuntutan yang terjadi di kampus atau perkuliahan.

Faktor yang lainnya adalah kondisi lingkungan, khususnya lingkungan rumah, keluarga, sekolah, dan masyarakat. Keadaan lingkungan yang baik, damai, tentram, aman, penuh penerimaan dan pengertian, serta mampu memberikan perlindungan kepada anggota-anggotanya akan memperlancar proses penyesuaian diri. Sebaliknya apabila individu tinggal di lingkungan yang tidak tentram, tidak damai, dan tidak aman, maka individu tersebut akan mengalami gangguan dalam melakukan proses penyesuaian diri.

Kebudayaan juga menjadi faktor yang berpengaruh dalam penyesuaian sosial termasuk adat istiadat dan agama (religiusitas). Religiusitas memberi nilai dan keyakinan sehingga individu memiliki arti, tujuan, dan stabilitas hidup yang diperlukan untuk menghadapi tuntutan dan perubahan yang terjadi dalam hidupnya (Schneiders, 1964: 161). Karakteristik budaya yang diturunkan kepada individu melalui keluarga, sekolah, lingkungan tempat tinggal, dan 
sebagainya merupakan suatu faktor yang membentuk watak dan tingkah laku individu untuk menyesuaikan diri dengan baik atau justru membentuk individu yang sulit menyesuaikan diri.

\section{Kesimpulan}

Berdasarkan hasil penelitian dan pembahasan yang telah dilakukan maka dapat disimpulkan bahwa:

1. Kecerdasan emosional mahasiswa FIP UPI berada pada kategori sedang. Hal ini menunjukkan bahwa mahasiswa FIP UPI memiliki kemampuan yang cukup baik dalam hal kesadaran diri, pengaturan diri, kesadaran sosial, dan pengaturan hubungan.

2. Penyesuaian sosial mahasiswa FIP UPI berada pada kategori sedang. Hal ini menunjukkan bahwa mahasiswa FIP UPI memiliki kemampuan yang cukup baik dalam menghargai dan menerima otoritas kampus; tertarik dan berpartisipasi dalam kegiatan kampus; mempunyai hubungan sosial yang sehat, bersahabat dengan teman, dosen, dan unsurunsur kampus lainnya; menerima batasan dan tanggung jawab sebagai mahasiswa; serta membantu kampus mencapai tujuan intrinsik dan ekstrinsik.

3. Terdapat hubungan yang signifikan antara kecerdasan emosional dengan penyesuaian sosial mahasiswa FIP UPI. Hubungan ini berkorelasi positif yang menunjukkan bahwa semakin tinggi kecerdasan emosional mahasiswa FIP UPI maka semakin baik penyesuaian sosialnya, sebaliknya semakin rendah kecerdasan emosional mahasiswa
FIP UPI maka semakin buruk pula penyesuaian sosialnya.

\section{Referensi}

Boyatzis., Goleman. (2005). Emotional competency inventory technical manual. Hay Group McClelland Center for Research and Innovation.

Effendi, I. N. (2003). Hubungan antara emotional intelligence dengan penyesuaian sosial di sekolah pada siswa kelas III SMUN 7 Bandung. Skripsi. Bandung: Fakultas Psikologi Universitas Islam Bandung.

Goleman, D. (2005). Kecerdasan emosi untuk mencapai puncak prestasi. Jakarta: PT Gramedia Pustaka Utama.

Goleman, D. (2007). Kecerdasan Emosional: Mengapa EI lebih penting daripada IQ. Jakarta: PT Gramedia Pustaka Utama.

Hurlock, E. B. (1980). Psikologi Perkembangan: Suatu Pendekatan Sepanjang Rentang Kehidupan. Jakarta: Erlangga.

Kamelia, D. (2003). Hubungan antara kecerdasan emosi dengan penyesuaian sosial di sekolah pada siswa kelas II SMU PGII II Bandung. Skripsi. Bandung: Fakultas Psikologi Universitas Islam Bandung.

Kapanlagi. (2008). Mahasiswa Atmajaya diduga bunuh diri karena depresi. Artikel tersedia di situs www.kapanlagi.com [9 Mei 2009].

Media Indonesia. (2010). Mahasiswa tawuran, pelajar saling lempar. Artikel tersedia di situs www.mediaindonesia.com [22 Oktober 2010]. 
Metrotvnews. (2008). Heboh mahasiswi ui bunuh diri dari lantai 7 PGC. Artikel tersedia di situs www.metrotvnews.com [9 Mei 2009].

Noorastuti, P. T. (2009). Tawuran antar mahasiswa UKI, 4 luka. Artikel tersedia di situs www.vivanews.com [22 Oktober 2010].

Schneiders, Alexander A. (1964). Personal adjustment and mental health. New York: Holt, Rinehart and Winston.

Sugiyono. (2008). Metode Penelitian pendidikan: Pendekatan kuantitatif, kualitatif, dan $R \& D$. Bandung: Alfabeta.

Thobias. (2008). Mahasiswa riwayatmu kini. Artikel tersedia di situs www.kemenegpora.go.id [9 Mei 2009]. 